ORIGINAL ARTICLE

\title{
The Relationship between Academic Self-Efficacy and Distance Education Perception in the Pandemic Process: A Study on Physical Education and Sports Teacher Candidates
}

\author{
TANER ATASOY ${ }^{1}$, AYDIN PEKEL ${ }^{2}$ \\ ${ }^{1}$ Assistant Professor, School of Physical Education and Sport, Istanbul Gelişim University, Istanbul, Turkey. https://orcid.org/0000-0001- \\ 8558-0663 \\ ${ }^{2}$ Assistant Professor, School of Physical Education and Sport, Istanbul Gelişim University, Istanbul, Turkey . https://orcid.org/0000-0003- \\ 0238-1081 \\ Corresponding author:Taner Atasoy.Email: tatasoy@gelisim.edu.tr
}

\begin{abstract}
The aim of this study is to examine the relationship between academic self-efficacy and distance education perception levels of physical education and sports teacher candidates during the pandemic process. The population of the study consists of teacher candidates $(n=908)$ studying at the physical education and sports teaching departments of the School of Physical Education and Sports and Sports Sciences within the private and public universities affiliated to the Higher Education Institution in Istanbul, and the sample consists of volunteers $(n=398)$ determined by simple random sampling method from this population. In order to collect data, the Google Forms platform was preferred in order to maintain social distance during the pandemic process. During the data collection process, information and questionnaires about the study were communicated to the participants through social networks. Volunteers who participated in the study were asked to fill in the personal information form, academic self-efficacy and distance education perception scales. The data obtained in the study were analyzed in computer environment. Variables are expressed by using mean \pm standard deviation, percentage and frequency values. Pearson product moments correlation analysis ( $r$ ) was applied to reveal the relationships between the scales. For the significance level of the tests, $p<0.05$ and $p<0.01$ values were accepted.

As a result, it was determined that the academic self-efficacy and distance education perception levels of physical education and sports teacher candidates were above the average. Between the academic self-efficacy and perception of distance education. A low level positive relationship was found. It is thought that this situation is caused by the concerns of physical education and sports teacher candidates, who are accustomed to the face-toface transfer of knowledge and skills related to the teaching models of sportive skills, to the transition to distance education and to the problems that may occur in this process and not to learn the necessary knowledge and skills related to their professional development.
\end{abstract}

Keywords: Physical Education and Sports, Academic Self-efficacy and Distance Education Perception

\section{INTRODUCTION}

Today, the cases and deaths that occur with the pandemic are known to change the flow and function of life all over the world. Various measures such as flexible working, working from home and working alternately have been implemented in order to reduce the impact of the pandemic, to slow down its spread due to its highly contagious nature and ensure social isolation. One of the measures taken in almost all countries is the short-term interruption of education and then the countries try to determine their own method of continuing education and training ${ }^{1}$. During this period, it is known that countries continue their education and training activities through distance education. Practices made with wrong concepts in order to save the day may eventually come up with a negative effect on the academic self-efficacy of learners.

Academic self-efficacy, which has an important place in every stage of education and training activities, expresses the belief that individuals can overcome academic tasks rather than their belief in their personal attitudes and abilities ${ }^{2}$. Accordingly, academic self-efficacy is expressed as a student's belief in the abilities s/he has in order to complete an academic task successfully. In addition, it is stated that there is a strong link between academic self-efficacy and academic achievement ${ }^{3}$. Academic self-efficacy can be strengthened with the positive experiences that will be experienced during the education process. Negative experiences that may arise with distance education practices during the pandemic process can have a negative effect. In this context, it is thought that negative perceptions of distance education and negative experiences of students who experience distance education for the first time will negatively affect the academic success of students. The aim of this study is examining the relationship between the academic selfefficacy and distance education perception levels of physical education and sports teacher candidates.

\section{MATERIAL AND METHOD}

Study Model: In the study, a method for descriptive survey and relational survey aiming to reveal the current situation was used. Descriptive survey models are a research approach that aims to describe a past or present situation as it exists. On the other hand, correlational survey models are research models aiming at determining the existence and/or degree of co-variation between two or more variables ${ }^{4}$.

Forming Volunteer Groups: The population of the study consisted of 908 teacher candidates studying in the physical education and sports teaching departments of the School of Physical Education and Sports and Sports Sciences faculties in the private and state universities 
affiliated to the Higher Education Institution in Istanbul, and the sample consisted of 398 volunteers determined by simple random sampling method.

\section{RESULTS}

Table 1. Descriptive statistics of the participants

\begin{tabular}{|l|l|l|l|}
\hline Variables & Groups & $\mathrm{N}$ & $\%$ \\
\hline \multirow{4}{*}{ Gender } & Female & 107 & 26.9 \\
\cline { 2 - 4 } & Male & 291 & 73.1 \\
\cline { 2 - 4 } & Total & 398 & 100 \\
\hline \multirow{4}{*}{ Age } & $18-20$ & 142 & 35.7 \\
\cline { 2 - 4 } & $21-23$ & 164 & 41.2 \\
\cline { 2 - 4 } & 24 and more & 92 & 23.1 \\
\cline { 2 - 4 } & Total & 398 & 100 \\
\hline \multirow{4}{*}{ Grade Point Average } & Private & 292 & 73.4 \\
\cline { 2 - 4 } & State & 106 & 26.6 \\
\cline { 2 - 4 } & Total & 398 & 100 \\
\hline & $0-1,99$ & 6 & 1.5 \\
\cline { 2 - 4 } & $2,00-2,99$ & 251 & 63.1 \\
\cline { 2 - 4 } & $3,00-4,00$ & 141 & 35.4 \\
\cline { 2 - 4 } & Total & 398 & 100 \\
\hline Weekly Study Time & $1-5$ & 271 & 68.1 \\
\hline & $6-10$ & 101 & 25.4 \\
\hline & 11 and more & 26 & 6.5 \\
\hline \multirow{2}{*}{ When } & Total & 398 & 100 \\
\hline
\end{tabular}

When Table 1 is examined, it was determined that according to gender variable, $26.9 \%$ of the physical education and sports teacher candidates who participated in the study were female and $73.1 \%$ of them were male; according to the age variable, $35.7 \%$ of them were $18-20$, $41.2 \%$ of them were $21-23,23.1 \%$ of them were 24 and more; according to the variable of the university where the students study, $73.4 \%$ of them study at private, $26.6 \%$ of them study at state university; according to the variable of grade point average, $1.5 \%$ of them had $0-1.99,63.1 \%$ of them had 2,00-2, 99 and $35.4 \%$ of them had 3.00-4.00; and according to the variable of weekly study time, $68.1 \%$ of them studied for $1-5,25.4 \%$ of them studied for $6-10$ and $6.5 \%$ of them studied for 11 hours or more.

Data Collection Tools: In order to collect data, the Google Forms platform was preferred in order to maintain social distance during the pandemic process. During the data collection process, information and questionnaires about the study were forwarded to the participants through social networks. Volunteers who participated in the study were asked to fill in the personal information form, academic selfefficacy and distance education perception scales.

Personal Information Form: Five questions including gender, age, university where the students study, grade point average and weekly study time were applied to the participants.

Academic Self-Efficacy Scale: The scale developed by Jerusalem and Schwarzer (1981) measures the academic self-efficacy levels of students with 7 items in one dimension ${ }^{5}$. The items were designed by using a 4-point Likert type scale. Cronbach Alpha value of the original scale was reported as .87. Turkish adaptation of the scale was made by Yılmaz et al (2007). The Turkish version of the scale was conducted to 672 candidate university students from different academic fields. The findings obtained from the analysis showed that the onedimensional and 7-item structure of the original scale was also preserved in the Turkish scale. Cronbach Alpha reliability value of the scale was presented as .796 .

Distance Education Perception Scale: The scale developed by Gündüz (2013) contains 20 items to determine the opinions of teacher candidates on the perception of distance education ${ }^{7}$. These items were designed by using a 5-point Likert-type scale. It was stated that the scale would be interpreted as one-dimensional. The Cronbach Alpha value of the scale was presented as 0,84 .

Data Analysis: The data obtained in the study were analyzed in computer environment. After checking the prerequisites for normality of variables and homogeneity of variances, Kolmogorov-Smirnov test was evaluated. Application of the Kolmogorov-Smirnov test is only one of the methods used to examine the state of normality. The skewness and kurtosis distributions according to the statistics of the data obtained in the study are given in Table 2.

Table 2. Skewness-Kurtosis and Kolmogorov-Smirnov test significance level results of participants' scale scores

\begin{tabular}{|l|l|l|l|l|}
\hline & $\mathrm{n}$ & Skewness & $\begin{array}{l}\text { Kurtosi } \\
\mathrm{s}\end{array}$ & $\mathrm{p}$ \\
\hline Academic Self-efficacy & 398 & -.282 & -.113 & .000 \\
\hline $\begin{array}{l}\text { Distance Education } \\
\text { Perception }\end{array}$ & 398 & .076 & -.526 & .107 \\
\hline
\end{tabular}

Looking at the Kolmogorov-Smirnov Test results in Table 2, it was observed that the scores of the physical education and sports teacher candidates on the distance education perception scale showed normal distribution, while the scores they got from the academic self-efficacy scale did not show a normal distribution. However, when the normal distribution curves were examined, it was seen that the deviations were not excessive and the values were in the \pm 1 range. In the literature, there are studies stating that these values are in the range of \pm 1 and that there is no excessive deviation from normality 8,9 . In line with this information, it was decided to apply normal distribution tests. Variables are expressed using mean \pm standard deviation, percentage and frequency values. Pearson product moments correlation analysis ( $r$ ) was applied to reveal the relationships between scales. For the significance level of the tests, $p<0,05$ and $p<0,01$ values were accepted.

Table 3. Descriptive statistics of the scores obtained from the scales

\begin{tabular}{|l|l|l|l|l|}
\hline & $\mathrm{n}$ & $\mathrm{Min}$ & $\mathrm{Max}$ & $\mathrm{X} \pm$ SD \\
\hline Academic Self-efficacy & 398 & 11.00 & 28.00 & $22.060 \pm 3.363$ \\
\hline $\begin{array}{l}\text { Distance Education } \\
\text { Perception }\end{array}$ & 398 & 25.00 & 100.00 & $62.686 \pm 16.456$ \\
\hline
\end{tabular}

When Table 3 was examined, it was determined that the academic self-efficacy level of the physical education and sports teacher candidates participating in the study was $22.060 \pm 3.363$ and their distance education perception level was $62.686 \pm 16.456$.

Table 4. The relationship between participants academic self-efficacy and distance education perception levels

\begin{tabular}{|l|l|l|}
\hline & & Distance Education Perception \\
\hline Academic Self-efficacy & $\mathrm{r}$ & .150 \\
\cline { 2 - 3 } & $\mathrm{p}$ & .003 \\
\cline { 2 - 3 } & $\mathrm{n}$ & 398 \\
\hline
\end{tabular}


When Table 4 was examined, a low level of positive correlation was detected between the academic selfefficacy and distance education perception of physical education and sports teacher candidates of $(r: .150$, $\mathrm{p}=.003)$.

\section{DISCUSSION and CONCLUSION}

As teaching is a profession that shapes the life style of individuals and society, it is one of the basic elements that make the education of a society effective and productive. In addition, teaching is considered to be a unique and leading profession in all professions because it undertakes the task of training staff for other professions ${ }^{10}$. In this context, teachers are important in terms of understanding students learning efforts and helping them to achieve learning ${ }^{11}$. However, in the process of transition to distance education with the Pandemic, many instructors had to move their course content online. In this case, it is obvious that it may cause some disruptions and handicaps in the education and training process for both the teacher and the learner.

It is seen that the academic self-efficacy levels and distance education perception of the physical education and sports teacher candidates participating in the study are above average. A low level positive correlation was found between the academic self-efficacy and distance education perception of physical education and sports teacher candidates. In other words, it is understood that as the academic self-efficacy level of teacher candidates increases, their distance education perception will also increase in the same direction.

When the literature was examined, no study was found that examined the relationship between distance education perception and academic self-efficacy. However, it is seen that there are separate studies on the general / academic self-efficacy ${ }^{2,12-16}$, and perception of distance education ${ }^{17-19}$

During the pandemic process, the distance education process has turned into a competence for educators, thus it has caused positive and negative perceptions on students. However, in the presented study, it is seen that academic self-efficacy level is not a very important determinant in distance education perception. The tendency for study pressure to increase as the level of academic self-efficacy increases; "To make more effort against failure and to quickly regain their lost efficacy beliefs", can be explained by its sensitivity ${ }^{20}$. İbicioğlu and Antalyalı (2005) stated in their study that the possibility of using computers, motivation and perception of distance education are of primary importance in success in distance education ${ }^{17}$. Individuals with high academic self-efficacy are able to adapt more easily to their environment and strive to overcome the tasks assigned to them ${ }^{21}$. Akkoyunlu and Kurbanoğlu, (2003) stated that it is important that students have high self-efficacy perceptions in using these knowledge and skills as well as having knowledge and skills about online technologies in the distance education process ${ }^{22}$.

As a result, it was determined that the academic selfefficacy and distance education perception levels of physical education and sports teacher candidates were above the average. Between the academic self-efficacy and perception of distance education a low level positive relationship was found. It is thought that this situation is caused by the concerns of physical education and sports teacher candidates, who are accustomed to the face-toface transfer of knowledge and skills related to the teaching models of sportive skills, to the transition to distance education and to the problems that may occur in this process and not to learn the necessary knowledge and skills related to their professional development.

\section{SUGGESTIONS}

- Studies that examine the relationship between the academic self-efficacy levels and distance education perception of teacher candidates in other branches can be conducted.

- $\quad$ Comparative studies can be conducted between the academic self-efficacy and distance education perception of larger-scale teacher candidates in physical education and sport.

\section{Authors' Contributions:}

Taner Atasoy: provided advice in solving problems about comparing the foundations of results and analysis the data and designed the study, prepared the plan, wrote the first draft of the manuscript and edited the final version.

Aydın Pekel: managed the literature searches and gathered theoretical foundations.

All authors read and approved the final manuscript.

Acknowledgments: The authors thanks all those who helped them in this research.

\section{REFERENCES}

1. Dikmen S, Bahçeci F. Strategies of Higher Education Institutions for Distance Education in the Covid-19 Pandemic Process: Example of Firat University. Turkish Journal of Educational Studies. 2020; 7 (2): 78-98.

2. Satıcı SA. Investıgation of Academıc Self-Effıcacy of University Students in Terms of Varıous Varıables. Higher License Thesis. Anadolu University Institute of Educational Sciences. 2013; Eskişehir.

3. Palavan Ö, Açar D. Investıgation of Academic Self-Efficacy of University Students in Terms of Various Variables. Journal of Trakya University Faculty of Education. 2016; 6(1): 14-27.

4. Karasar N. Scientific Research Instruction. 2004; Ankara: Nobel Yayıncilık.

5. Jerusalem M, Schwarzer R. Fragebogen zur Erfassung von" Selbstwirksamkeit. Skalen zur Befindlichkeit und Persoenlichkeit In R. Schwarzer (Hrsg.).(Forschungsbericht No.5). 1981; Berlin: Freie Universitaet, Institut fuer Psychologie.

6. Yılmaz M, Gürçay D, Ekici G. Adaptatıon of the Academıc Self-Effıcacy Scale to Turkısh. Hacettepe Üniversitesi Eğitim Fakültesi Dergisi. 2007; 33: 254-259.

7. Gündüz AY. Preservice teachers' perception of distance education. Higher License Thesis. Sakarya University Institute of Educational Sciences Department of Computer Education and Instructional Technologies. 2013; Sakarya.

8. Büyüköztürk Ş. Handbook of Data Analysis for the Social Sciences, (7th ed.). 2007; Ankara: Pegem Academy Publishing.

9. George D, Mallery P. IBM SPSS Statistics 23 Step by Step: A Simple Guide and Reference. 2016; New York: Routledge.

10. Alkan C. Profession and Teaching Profession. (Ed. Sönmez, V.) Introduction to the Teaching Profession. 2000; Ankara: Anı Publisher 
11. Martınez-Pons M. Effective transfer as a self-regulatory process: Implications for adult education. In: Royaumont Symposium on Self-Learning, Paris. 2000.

12. Aksu N. The research of the relationship between the academic self-competence, social relation elements and crime tendency of the high school stodents. Higher License Thesis. Zirve University. 2015; Gaziantep.

13. Albayrak E. Personality, academic self-efficacy, academic locus of control and academic procrastination among university students. Higher License Thesis. Karadeniz Teknik Üniversitesi. 2014; Trabzon.

14. Dalbudak I, Musa M. Analysis of self-efficacy-sufficiency levels of individuals with visual impairment according to some variables. International Education Studies. 2019; 12(10): 75-88.

15. Akıncı AY. The relationship between teacher candidate's self-efficacy and attitudes of sports history. International Education Studies. 2020; 13 (7): 105-112.

16. Turan M, Karaoğlu B, Kaynak K, Pepe O. Examinatıon of the general self-efficacy of candidates who took the special ability exam according to some variables. Spor Bilimleri Araştırmaları Dergisi. 2016; 1 (1): 17-26.

17. İbicioğlu H, Antalyalı ÖL. Opportunities, Perception, Motivation and Success in Distance Education Effects of Interaction Factors: A Comparative Application. Ç.Ü. Sosyal
Bilimler Enstitüsü Dergisi. 2005; 14 (2): 325-338.

18. Kışla T. University students' attitudes towards distance education. Higher License Thesis. Ege University Institute of Social Sciences. 2005; İzmir.

19. Başar M. Arslan S. Günsel E. Akpınar M. Distance education perceptions of prospective teachers. Journal of Multidisciplinary Studies in Education. 2019; 3(2): 14-22.

20. Bandura A. Perceived self-efficacy in cognitive development and functioning. Educational Psychologist. 1993; 28(2): 117148.

21. Journal of Yalnız A. Akademik öz-yeterlik: Academic selfefficacy: Predictive roles of positive and negative affect. Journal of Education and Training Research. 2017; 3(2): 95110.

22. Akkoyunlu B, Kurbanoğlu S. A study on teacher candidates' perceived information literacy self-efficacy and perceived computer self-efficacy. Journal of Hacettepe University Faculty of Education. 2003; 24: 1-10.

23. Abbasi, R., Chobtashani, S., Salehian, M.H., Sarvari. S. Comparison of the effect of play therapy and selected sports exercises on self-confidence, physical self-efficacy and mental stubbornness in children, International Pediatrics. 2021. 10.22038/ijp.2021.57739.4527 